\title{
PHYTOCHEMICAL ANALYSIS AND ANTIBACTERIAL AND ANTIOXIDANT PROPERTIES OF INDIGOFERA TINCTORIA L.
}

\section{CHANDRASEKARAN SWAMINATHAN*}

Department of Microbiology, St. Joseph's College of Arts and Science (Autonomous), Cuddalore, Tamil Nadu, India. Email: actinosam@yahoo.com

Received: 18 May 2017, Revised and Accepted: 19 February 2018

\section{ABSTRACT}

Objective: The present study was designed to evaluate the phytochemical composition and antibacterial and antioxidant potential of methanolic leaf and root extracts of Indigofera tinctoria L.

Methods: Phytochemical analysis was done using standard methods. The methanolic leaf and root extracts of the plant were tested against Staphylococcus aureus, Enterococcus faecalis, Klebsiella pneumoniae, Enterobacter aerogenes, and Salmonella paratyphi B by cup-plate agar diffusion method. The free radical scavenging activities of the methanol extracts of leaves and roots were evaluated by 2,2-diphenyl-1-picrylhydrazyl (DPPH) assay.

Results: Phytochemical screening revealed the presence of carbohydrates, reducing sugars, alkaloids, saponins, phenolic compounds, and flavonoids in methanolic leaf and root extracts. Methanolic leaf extracts of the plant exhibited antibacterial activity against a wide range of bacteria, but the root extracts failed to inhibit the tested bacterial pathogens. The antioxidant activity determination revealed that at $100 \mu \mathrm{g} / \mathrm{ml}$, methanolic root extracts had the highest antioxidant activity (89.10\%) on DPPH free radicals followed by methanolic leaf extracts (46.74\%).

Conclusion: The results of the present study conclude that the studied plant possesses broad-spectrum antibacterial and antioxidant properties and may act as a potent antioxidant for biological systems susceptible to free radical-mediated reactions.

Keywords: Indigofera tinctoria L., Methanol extract, Phytochemical analysis, Antibacterial activity, 2,2-diphenyl-1-picrylhydrazyl assay.

(c) 2018 The Authors. Published by Innovare Academic Sciences Pvt Ltd. This is an open access article under the CC BY license (http://creativecommons. org/licenses/by/4. 0/) DOI: http://dx.doi.org/10.22159/ajpcr.2018.v11i6.20060

\section{INTRODUCTION}

The search for novel antimicrobial and antioxidants from natural sources has increased in response to the emergence of drugresistant microorganisms and negative health effects of synthetic antioxidants $[1,2]$. Herbal drugs have gained a reputation in recent years because of their safety, efficacy, and cost-effectiveness. In the present day, nearly four billion people living in the developing world depend on plant-derived medicines as their first line of action for combating diseases and maintaining health [3-5].

Indigofera tinctoria Linn. (Fabaceae) is a leguminous plant which is widespread across tropical regions around the globe, as it had been cultivated and highly valued for centuries as the main source of indigo dye, leading to its common names "true indigo" and "common indigo." In traditional medicine, the plant is useful in the treatment of cancer, hydrophobia, gout, rheumatoid arthritis, cephalalgia, lumbago, epilepsy, insanity, blennorrhagia, urinary complaints, cough, bronchitis, rhinitis, asthma, palpitation, hepatitis, splenomegaly, hemorrhoids, sores, old ulcers, constipation, leucoderma, grey hairs, snake bite, scorpion bite, and insect bite [6-8]. In Africa, the indigo powder used in calendering also served as a disinfectant and cicatrizing drug to aid in the formation of scar tissue as part of the practice of tattooing. In Cameroon, the twigs are still commonly used as a toothbrush, and the roots have been widely applied as a treatment for a toothache. A root preparation is applied in Tanzania as a remedy against syphilis, gonorrhea, and kidney stone [9]. The plant also possesses antibacterial [10], anti-inflammatory [11], antidiabetic [12], antiHIV [13], immunomodulatory [14], antidepressant, and nootropic activity [15]. However, few reports are currently available in the literature regarding the antimicrobial and antioxidant activities of leaves and roots of the plant. In the continuation of the strategy of new drug discovery, the present study investigates the phytochemical constituents, antibacterial and antioxidant properties of the methanolic leaf and root extracts of I. tinctoria $\mathrm{L}$.

\section{METHODS}

Collection and processing of plant materials

The plant I. tinctoria L. free from disease was collected from Kolli hills, Tamil Nadu, India. The identification of the plant was carried out by Dr. A. Balasubramanian, ABS Botanical Conservation, Research, and Training Centre, Salem. The leaves and roots were washed under running tap water, air dried, and homogenized to powder form and stored in the airtight bottle.

\section{Preparation of plant extracts}

Leaf powder (20 g) and root powder (20 g) were soaked separately in $200 \mathrm{ml}$ of methanol in a conical flask and kept for 2 days at room temperature in laboratory shaker with a shaking speed of $120 \mathrm{rpm}$. The extracts so obtained were filtered through Whatman No. 1 filter paper. The filtrates were concentrated using a rotary evaporator under reduced pressure and then stored at $4^{\circ} \mathrm{C}$ for further analyses [2]

\section{Phytochemical screening}

The crude methanolic leaf and root extracts of I. tinctoria L. were tested for the presence of phytochemicals using standard phytochemical methods [16-18]

\section{Test bacterial strains}

Clinical isolates of Staphylococcus aureus, Enterococcus faecalis, Klebsiella pneumoniae, Enterobacter aerogenes, and Salmonella paratyphi B were obtained from Sri Gokulam Hospital, Salem, India. Pure bacterial cultures were maintained on nutrient agar slants at $4{ }^{\circ} \mathrm{C}$ 
Determination of antibacterial activity

To determine the antibacterial activity of methanolic leaf and root extracts, cup-plate agar diffusion method was adopted [19]. The bacterial cultures were grown in brain-heart infusion (BHI) broth and incubated at $37^{\circ} \mathrm{C}$ for $24 \mathrm{~h}$. The cultures were later diluted with sterile medium, adjusted to 0.5 McFarland turbidity standard and inoculated on BHI agar plates by streaking the organisms over the surface of the medium using a sterile cotton swab and allowed to dry for about $10 \mathrm{~min}$. Four wells of $6 \mathrm{~mm}$ in diameter and $4 \mathrm{~mm}$ in depth were cut using a sterile cork borer, maintaining a distance of $3 \mathrm{~cm}$ between them. The wells were filled with $100 \mu \mathrm{l}$ of methanolic leaf and root extracts $(100 \mathrm{mg} / \mathrm{ml})$ dissolved in dimethyl sulfoxide (DMSO). Wells filled with $100 \mu \mathrm{l}$ of nalidixic acid $(500 \mu \mathrm{g} / \mathrm{ml})$ and $100 \mu \mathrm{l}$ of DMSO served as positive and negative controls, respectively. The plates were then kept at room temperature in an upright position for $2 \mathrm{~h}$ for diffusion of extracts and then incubated under the same growth conditions as mentioned above. Antibacterial activity was determined by measuring the inhibition zones formed around each well, averaged and the mean values were noted.

Antioxidant activity determination by 2,2-diphenyl-1picrylhydrazyl (DPPH) radical scavenging assay

Free radical scavenging ability of methanolic leaf and root extracts and standard synthetic antioxidant used in the study prepared in methanol at concentrations of $20-100 \mu \mathrm{g} / \mathrm{ml}$ was determined in accordance with the Shimada et al.'s method [20] which is based on the principle of scavenging the DPPH. DPPH was added to the solutions prepared with plant extracts and standard antioxidant substance ascorbic

Table 1: Phytochemical screening of methanolic leaf and root extracts of I. tinctoria $\mathrm{L}$.

\begin{tabular}{|c|c|c|}
\hline Phytochemical tests & $\begin{array}{l}\text { Methanolic leaf } \\
\text { extract }\end{array}$ & $\begin{array}{l}\text { Methanolic root } \\
\text { extract }\end{array}$ \\
\hline \multicolumn{3}{|l|}{ Carbohydrates } \\
\hline Molisch's test & + & + \\
\hline \multicolumn{3}{|l|}{ Reducing sugars } \\
\hline Fehling's test & + & + \\
\hline Benedict's test & + & + \\
\hline \multicolumn{3}{|l|}{ Alkaloids } \\
\hline Mayer's test & + & + \\
\hline Dragendorff's test & + & + \\
\hline Hager's test & + & + \\
\hline Wagner's test & + & + \\
\hline \multicolumn{3}{|l|}{ Phytosterol } \\
\hline Salkowski test & + & - \\
\hline \multicolumn{3}{|l|}{ Fixed oil } \\
\hline Spot test & - & - \\
\hline \multicolumn{3}{|l|}{ Saponins } \\
\hline Froth test & + & + \\
\hline \multicolumn{3}{|l|}{$\begin{array}{l}\text { Proteins and free amino } \\
\text { acids }\end{array}$} \\
\hline Xanthoprotein test & + & - \\
\hline \multicolumn{3}{|l|}{ Phenolic compounds } \\
\hline Ferric chloride test & + & + \\
\hline \multicolumn{3}{|l|}{ Flavonoids } \\
\hline Alkaline reagent test & + & + \\
\hline
\end{tabular}

acid and stirred. The samples were kept in the dark for $30 \mathrm{~min}$ and the absorbance was measured at $517 \mathrm{~nm}$ against a blank. Radical scavenging activity was calculated by the following formula.

Percentage Inhibition $=($ control OD-sample OD $/($ control OD $) \times 100$

\section{RESULTS}

The results of the phytochemical screening of the investigated methanolic leaf and root extracts of I. tinctoria L. showed the presence of carbohydrates, reducing sugars, alkaloids, saponins, phenolic compounds, and flavonoids in methanolic leaf and root extracts, whereas, phytosterol, proteins, and free amino acids were detected only in methanolic leaf extracts. Fixed oil was not detected in both methanolic leaf and root extracts (Table 1 ).

The antibacterial activity of methanolic leaf and root extracts of I. tinctoria L. was tested against five bacterial pathogens with nalidixic acid as a positive control and DMSO as a negative control (Table 2). The methanolic leaf extracts of $I$. tinctoria L. showed promising antibacterial activity against a wide range of bacteria, while methanolic root extracts inhibited none of the tested bacterial pathogens. Maximum in vitro inhibition was scored by E. faecalis, followed by $S$. aureus, S. paratyphi B, E. aerogenes, and K. pneumoniae, which presented inhibition zone diameter of $26.66 \pm 0.57 \mathrm{~mm}, 24.33 \pm 0.57 \mathrm{~mm}$, $22.33 \pm 0.57 \mathrm{~mm}, 20.66 \pm 0.57 \mathrm{~mm}$, and $18.33 \pm 0.57 \mathrm{~mm}$, respectively.

The antioxidant activity of methanolic leaf and root extracts of I. tinctoria L. as measured by the ability to scavenge DPPH free radicals was compared with the standard ascorbic acid. The results of DPPH assay revealed that methanolic leaf and root extracts exhibited significant antioxidant activity (Fig. 1). The DPPH scavenging effect was found to increase with increasing concentrations. At $100 \mu \mathrm{g} / \mathrm{ml}$, the highest percentage inhibition (89.10\%) was shown by methanolic root extract compared to the reference antioxidant ascorbic acid ( $77.71 \%$ inhibition) followed by $46.74 \%$ inhibition by methanolic leaf extracts.

\section{DISCUSSION}

Plants are the important source of bioactive compounds for the development of potential chemotherapeutic agents [21]. Phytochemical investigation of methanolicleaf and root extracts of $I$. tinctoria L. revealed the presence of various phytochemicals. Flavonoid is known to have a wide range of therapeutic properties as antimicrobial, antioxidative, antirheumatism, and chemopreventive agents. Phenolic compounds are identified as antioxidative and scavenging agents against oxidative damage associated with free radicals $[8,22]$. As phytochemicals often play a significant role in plant defense against plant pathogens, stress as well as interspecies protections, these phytochemicals have been used as drugs for millennia [23].

By cup-plate agar diffusion method, the methanolic leaf extracts showed good antibacterial activity, evidencing that methanol is an efficient organic solvent to be used for the extraction of bioactive plant materials. Renukadevi and Sultana [10] reported that methanol extract of $I$. tinctoria L. showed antibacterial activity against $S$. aureus, Streptococcus pyogenes, and Bacillus pumilus. Vijayan et al. [24]

Table 2: Antibacterial activity of methanolic leaf and root extracts of $I$. tinctoria L.

\begin{tabular}{lllll}
\hline $\begin{array}{l}\text { Bacterial } \\
\text { pathogens }\end{array}$ & \multicolumn{2}{l}{ Diameter of zone of inhibition (mm) } & & Methanolic leaf extract \\
\cline { 2 - 5 } & Nalidixic acid & DMSO & Nil & Methanolic root extract \\
\hline S. aureus & $29.33 \pm 1.15$ & $\mathrm{Nil}$ & $24.33 \pm 0.57$ & $\mathrm{Nil}$ \\
E. faecalis & $22.66 \pm 1.52$ & $\mathrm{Nil}$ & $26.66 \pm 0.57$ & $\mathrm{Nil}$ \\
K. pneumoniae & $26.33 \pm 0.57$ & $\mathrm{Nil}$ & $18.33 \pm 0.57$ & $\mathrm{Nil}$ \\
E. aerogenes & $20.66 \pm 0.57$ & $\mathrm{Nil}$ & $20.66 \pm 0.57$ & $\mathrm{Nil}$ \\
S. paratyphi B & $27.33 \pm 1.15$ & $22.33 \pm 0.57$ & $\mathrm{Nil}$ \\
\hline
\end{tabular}

Values are means of triplicate determinations \pm standard deviation. DMSO: Dimethyl sulfoxide, I. tinctoria: Indigofera tinctoria, S. aureus: Staphylococcus aureus,

E. faecalis: Enterococcus faecalis, K. pneumoniae: Klebsiella pneumoniae, E. aerogenes: Enterobacter aerogenes, S.paratyphi B: Salmonella paratyphi B 


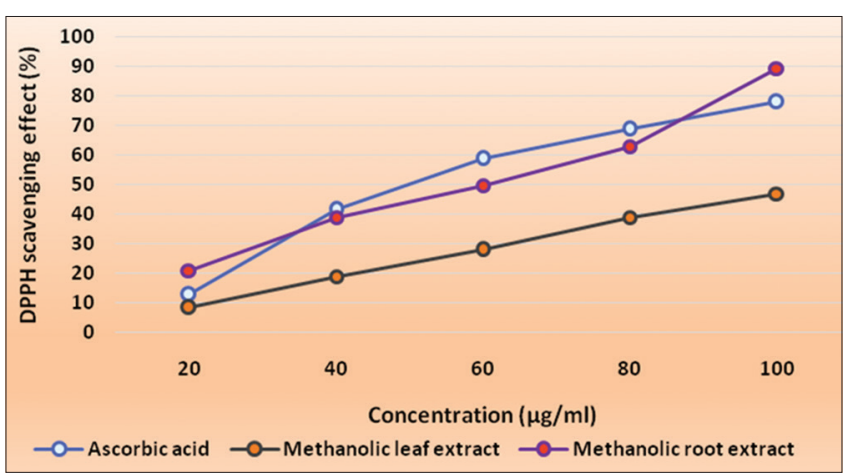

Fig. 1: 2,2-diphenyl-1-picrylhydrazyl free radical scavenging activity of methanolic leaf and root extracts of Indigofera tinctoria L. Values are means of triplicate determinations \pm standard deviation. DPPH: 2,2-diphenyl-1-picrylhydrazyl

have reported that methanol extract of leaves of the plant showed antibacterial activity against methicillin-resistant $S$. aureus, E. faecalis, Moraxella catarrhalis, Haemophilus influenzae, and anaerobes. In the present study, the differences in sensitivity of tested bacterial pathogens to methanolic leaf and root extracts of I. tinctoria L. may be explained by the differences in cell wall composition and/or in genetic content of plasmids that can be easily transferred among microbial strains [25]. It may also be described by differences in the mechanism by which the active principles of the plant extracts exert their action and the concentration of the extract employed [26,27].

The DPPH scavenging activity is due to the neutralization of free radical by the methanolic leaf and root extracts of I. tinctoria L. either by transfer of hydrogen or of an electron [28]. Free radical scavenging is the recognized mechanism for antioxidant-inhibiting lipid oxidation [29]. The highest free radical scavenging activity of methanolic leaf and root extracts of the plant corroborates with the results of Srinivasan et al. [8] and Bakasso et al. [30].

\section{CONCLUSION}

The results obtained from the present study suggest that I. tinctoria $\mathrm{L}$. is a potential source of antibacterial and antioxidant molecules. Bioassayguided fractionation procedure should be performed to characterize and isolate the phytochemical responsible for the antibacterial and antioxidant activity. Furthermore, they should be subjected to pharmacological evaluation with the objective of assessing theirs in vivo efficacy, toxicity, potential adverse effects, interactions, and contraindications.

\section{ACKNOWLEDGMENT}

The author expresses his sincere thanks to Rev. Fr. Secretary, St. Joseph's College of Arts and Science (Autonomous), Cuddalore, India, for his encouragement.

\section{REFERENCES}

1. Noumedem JA, Tamokou Jde D, Teke GN, Momo RC, Kuete V, Kuiate JR, et al. Phytochemical analysis, antimicrobial and radicalscavenging properties of Acalypha manniana leaves. Springerplus 2013;2:503

2. Swaminathan C. Evaluation of antibacterial and antioxidant properties of Cleome viscosa L. Indo Am J Pharm Res 2017;7:8473-8.

3. Singh A. Medicinal Plants of the world. New Delhi: Oxford and IBH Publishing Co. Pvt. Ltd.; 2006.

4. Bandaranayake WM. Quality control, screening, toxicity and regulation of herbal drugs. In: Ahmad I, Aquil F, Owais M, editors. Modern Phytomedicine: Turning Medicinal Plants in to Drugs. Weinheim: Wiley-VCH Verlag GmbH and Co. KGaA; 2006.

5. Govindarajan M, Jebanesan A, Reetha D, Amsath R, Pushpanathan T, Samidurai K, et al. Antibacterial activity of Acalypha indica L. Eur Rev Med Pharmacol Sci 2008;12:299-302.
6. Duke JA. Handbook of Legumes of World Economic Importance. New York: Plenum Press; 1981.

7. Anusuya N, Manian S. Antioxidant and free radical scavenging potential of different solvent extracts of Indigofera tinctoria L. Leaves. Int J Pharm Pharm Sci 2013;5:142-7.

8. Srinivasan S, Wankhar W, Rathinasamy S, Rajan R. Free radical scavenging potential and HPTLC analysis of Indigofera tinctoria Linn (Fabaceae). J Pharm Anal 2016;6:125-31.

9. Shujaa MJ, Shujaa KJ. The SAGE Encylopedia of African Cultural Heritage in North America. Thousand Oaks: SAGE Publications; 2015.

10. Renukadevi KP, Sultana S. Determination of antibacterial, antioxidant and cytotoxicity effect of Indigofera tinctoria on lung cancer cell line NCI-h69. Int J Pharmacol 2011;7:356-62.

11. Tyagi KP, Rai VK, Pahria AK, Kumar SS, Singh Y, Sharma M. Preliminary phytochemical screening and evaluation of antiinflammatory activity of ethanolic extract of leaves of Indigofera tinctoria Linn. J Curr Pharm Res 2010;3:47-50.

12. Verma SM, Suresh KB, Amit V. Antidiabetic activity of leaves of Indigofera tinctoria Linn (Fabaceae). Int J Toxicol Pharm Res 2010:1:42-3.

13. Kavimani S, Jaykar B, De-Clerq E, Pannecouque C, Witvrouw M. Studies on anti-HIV activity of Indigofera tinctoria. Hamdard Med 2000;43:5-7

14. Boothapandi M, Ramanibai R. Immunomodulatory activity of Indigofera tinctoria leaf extract on in vitro macrophage responses and lymphocyte proliferation. Int J Pharm Pharm Sci 2016;8:58-63.

15. Chowdhury AA, Juvekar AR. Antidepressant and nootropic activity of aqueous extract of Indigofera tinctoria in mice. Int J Pharm Pharm Sci 2014;6:131-5

16. Harborne JB. Phytochemical Methods. A Guide to Modern Techniques of Plant Analysis. $3^{\text {rd }}$ ed. New Delhi: Springer Science and Business Media; 1998.

17. Evans WC. Trease and Evans' Pharmacognosy. 13 $3^{\text {th }}$ ed. London: Bailliere Tindal Publishers; 1989

18. Santhi M, Swaminathan C. Evaluation of antibacterial activity and phytochemical analysis of leaves of Withania somnifera (L.) Dunal. Int J Curr Res 2011;3:10-2.

19. Urizar GU, Anguilar-Luis MA, Lama-Odria MD, Lizarzaburu JC, Mendoza JD. Antibacterial activity of five Peruvian medicinal plants against Pseudomonas aeruginosa. Asian Pac J Trop Biomed 2015;5:928-31.

20. Shimada K, Fujikawa K, Yahara K, Nakamura T. Antioxidative properties of xanthone on the auto oxidation of soybean in cyclodextrin emulsion. J Agr Food Chem 1992;40:945-8.

21. Sukumaran S, Kiruba S, Mahesh M, Nisha SR, Miller PZ, Ben CP, et al. Phytochemical constituents and antibacterial efficacy of the flowers of Peltophorum pterocarpum (DC.) baker ex heyne. Asian Pac J Trop Med 2011;4:735-8.

22. Sharma V, Agarwal A. Physicochemical and antioxidant assays of methanol and hydrothermal extract of ariel parts of Indigofera tinctoria Linn. Indian J Pharm Sci 2015;77:729-34.

23. Chew YL, Chan EW, Tan PL, Lim YY, Stanslas J, Goh JK, et al. Assessment of phytochemical content, polyphenolic composition, antioxidant and antibacterial activities of leguminosae medicinal plants in peninsular Malaysia. BMC Complement Altern Med 2011;11:12.

24. Vijayan M, Jacob K, Govindaraj Y. Antibacterial activity and mutagenicity of leaves of Indigofera tinctoria Linn. J Exp Integr Med 2012;2:263-9

25. Karaman I, Sahin F, Gulluce M, Ogutcu H, Sengul M, Adiguzel A. Antimicrobial activity of aqueous and methanol extracts of Juniperus oxycedrus L. J Ethnopharmacol 2003;85:231-5.

26. Takeo O, Masato K, Keiko S, Rika O, Junko M, Hiroshi I. In vitro and in vivo antibacterial activities of tricyclic ketolide TE-802 and its analogs. J Antibiot (Tokyo) 2004;57:518-27.

27. Srinivasan S, Wankhar W, Rathinasamy S, Rajan R. Larvicidal potential of Indigofera tinctoria (Fabaceae) on Dengue vector (Aedes aegypti) and its antimicrobial activity against clinical isolates. Asian J Pharm Clin Res 2015;8:316-9.

28. Chairman K, Singh R, Alagumuthu G. Cytotoxic and antioxidant activity of selected marine sponges. Asian Pac J Trop Dis 2012;2:234-8.

29. Williams WB, Cuvulier ME, Berset C. Use of a free radical method to evaluate antioxidant activity. Food Sci Technol 1995;28:25-30.

30. Bakasso SA, Lamien-Meda A, Lamien CE, Kiendrebeogo M, MillogoJ, Quedraogo AG. Polyphenol contents and antioxidant activities of five Indigofera species (Fabacea) from Burkina Faso. Pak J Biol Sci 2008;11:1429-35. 